\title{
Anconeus Epitrochlearis Muscle as a Cause of Ulnar Nerve Compression at the Elbow
}

\section{Músculo anconeu epitroclear como causa de compressão do nervo ulnar no cotovelo}

\author{
Luiz Fernando Cannoni ${ }^{1}$ Luciano Haddad ${ }^{1}$ \\ ${ }^{1}$ Neurológika Ltda, São Paulo, SP, Brazil \\ Arq Bras Neurocir 2017;36:190-193.
}

Address for correspondence Luiz Fernando Cannoni, PhD, Rua \begin{abstract}
Conselheiro Cotegipe, 543, Belenzinho, São Paulo, SP, CEP 03058-000,
\end{abstract} Brazil (e-mail: luiz2603@terra.com.br).

\begin{abstract}
Keywords

- ulnar nerve disease

- ulnar neuropathy
\end{abstract}

Ulnar nerve entrapment is the second most common compressive neuropathy in the upper limb, after carpal tunnel syndrome (Dellon, 1986). One of the causes that must be considered is the accessory anconeus epitrochlearis muscle, which is present in $4 \%$ to $34 \%$ of the general population (Husarik et al, 2010; Vanderpool et al, 1968; Nellans et al, 2014).

We describe a patient with symptoms of compression of the left ulnar nerve at the elbow and the result of the surgical treatment.

The patient presented with hypoesthesia in the fourth and fifth fingers of the left hand, and reduction of strength in the fifth finger abduction. No alterations were found in the thumb adduction.

Initially, the treatment was conservative (splint, physiotherapy, analgesics); surgical treatment was indicated due to the continuity of the symptoms.

The ulnar nerve was surgically released and transposed, with complete recovery after 6 months of follow-up.

Ulnar nerve entrapment at the elbow by the anconeus epitrochlearis muscle is not common, but it must not be ignored (Chalmers, 1978). Ultrasonography (Jung et al, 2013; Bargalló et al, 2010), elbow magnetic resonance imaging (MRI) (Jeon, 2005), and electromyography (Byun, 2011) can help establish the proper diagnosis.

\section{Resumo}

A compressão do nervo ulnar é a segunda causa mais frequente de neuropatia compressiva no membro superior, após a síndrome do túnel do carpo (Dellon, 1986). Uma das causas que dever ser considerada é a presença do músculo anconeu epitroclear, que está presente em cerca de $4 \%$ a 34\% da população (Husarik et al, 2010; Vanderpool et al, 1968; Nellans et al, 2014).

Descrevemos uma paciente com sintomas de compressão do nervo ulnar esquerdo no cotovelo, e o resultado do tratamento cirúrgico. received

May 31, 2017

accepted

July 17,2017

published online

August 28, 2017
DOI https://doi.org/

10.1055/s-0037-1606276.

ISSN 0103-5355.
Copyright (e 2017 by Thieme Revinter

Publicações Ltda, Rio de Janeiro, Brazil
License terms

(c) (i) $\ominus$ (\$) 


\section{Palavras-chave}

- lesões do nervo ulnar

- patologia do nervo ulnar
A paciente apresentava hipoestesia no IV e V dedos da mão esquerda, e diminuição de força na abdução do $V$ dedo; não foram encontradas alterações na adução do polegar. Inicialmente, o tratamento foi conservador (uso de splint, fisioterapia e analgésicos); a cirurgia foi indicada pela persistência dos sintomas.

O nervo ulnar foi cirurgicamente liberado e transposto, com melhora total dos sintomas após 6 meses de acompanhamento.

A compressão do nervo ulnar no cotovelo não é comum, mas não deve ser ignorada (Chalmers, 1978). Ultrassonografia (Jung et al, 2013; Bargalló et al, 2010), ressonância magnética do cotovelo (Jeon, 2005) e eletromiografia (Byun, 2011) auxiliam no diagnóstico.

\section{Introduction}

Ulnar nerve entrapment is the second most common compressive neuropathy after carpal tunnel syndrome. ${ }^{1}$ The ulnar nerve can be compressed at various points along its trajectory, but most cases are localized on the elbow and the Guyon canal. ${ }^{10}$

Of the many causes of ulnar neuropathy, the most common are traumatic and idiopathic in nature. The anconeus epitrochlearis muscle, first described by Scafer and Schaeffer, is a well-known, but rare cause of ulnar nerve entrapment at the elbow. ${ }^{2}$ This muscle is present in $4 \%$ to $34 \%$ of the general population. ${ }^{1,3,11}$

The anconeus epitrochlearis is an anomalous muscle located between the medial aspect of the ulnar olecranon and the medial epicondyle, and it is found in up to $28 \%$ of cadavers. ${ }^{1}$ The authors report the case of a 34 -year-old woman with a 6 -month history of left elbow pain and distal motor and sensory symptoms affecting her daily activities and quality of life. After a conservative treatment that included physiotherapy and the use of a splint, and of analgesic and anti-inflammatory drugs, surgical excision of the muscle and decompression of the ulnar nerve was proposed.

The patient agreed to the disclosure of all data (including surgical pictures), signing the informed consent form. None of the authors had conflicts of interest.

\section{Case Report}

We describe the case of a 34-year-old female patient, a righthanded secretary who presented pain at the left forearm for 6 months, followed by progressive sensitive and motor disturbances on the medial side of the left forearm. She had spent years answering telephone calls supporting her left elbow on the table.

The patient presented hypoesthesia in the fourth and fifth fingers, and reduction of strength in the fifth finger abduction. Numbness and tingling were localized to the ulnar side of the forearm and the two ulnar side digits. Upon physical examination, she had a positive Tinel sign on the medial surface of the elbow. Froment sign was also present. We did not observe any alteration in the function of the abduction of the left thumb.

She was submitted to magnetic resonance imaging (MRI), radiography and electromyography (EMG) of the left elbow to confirm the diagnosis. The EMG described compression of the nerve in the ulnar groove, with conduction block and a large drop in nerve conduction velocity. Plain radiographs of the left upper limb were normal.

The MRI showed ulnar nerve compression at the elbow by the anconeus epitrochlearis muscle ( $\mathbf{- F i g . 1} \mathbf{1}$ ).

After a period of conservative treatment, surgical treatment was indicated and performed through a medial epicondylar incision, with division of the anconeus

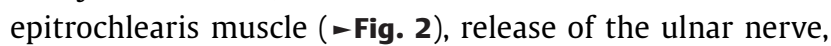
and preservation of the branches to the flexor carpi ulnaris. The resection of the muscle is shown in - Fig. 3

Nerve transposition to subcutaneous fatty tissue was performed without epicondylectomy. Recovery of both motor and sensory nerve functions can be achieved if the source of compression is an anomalous muscle that is treated with early surgical removal. ${ }^{9,12}$ In the follow-up period (6 months), the patient was fully recovered.

This patient also complained about the symptomatology in the right side, with a confirmed right anconeus epitrochlearis muscle by MRI, but on this side, the symptoms were very smooth, leading to a conservative treatment.

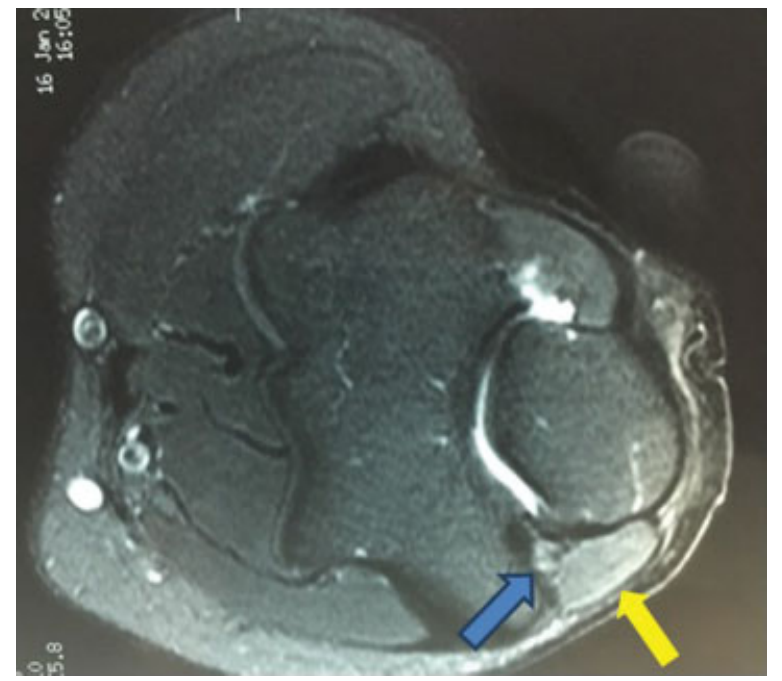

Fig. 1 MRI of the left elbow depicting the ulnar nerve (blue arrow) and the anconeus epitrochlearis muscle (yellow arrow). 


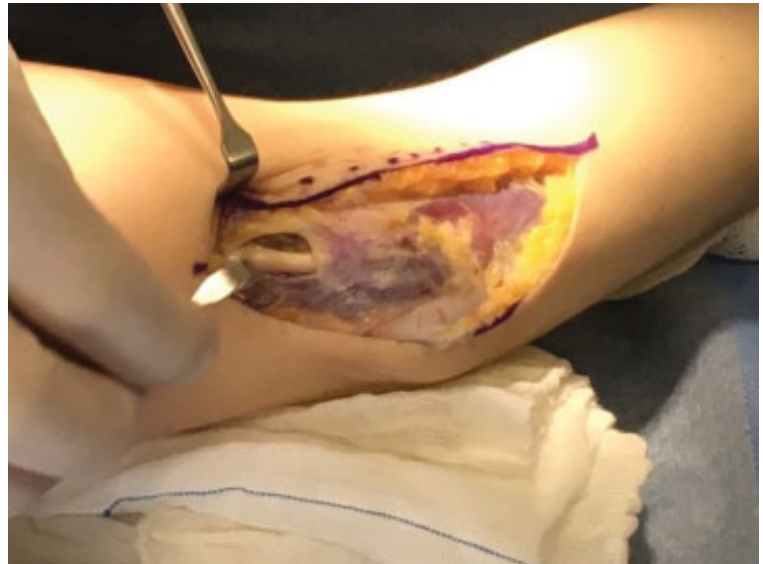

Fig. 2 Exposition of the ulnar nerve (blue arrow) under the anconeus epitrochlearis muscle (yellow arrow).

\section{Anconeus Epitrochlearis Muscle}

The anconeus epitrochlearis muscle is an accessory muscle of the medial elbow that originates from the medial epicondyle of the humerus and inserts on the olecranon process of the ulna, and as an extension of the medial head of the triceps brachii. ${ }^{12}$

Anatomical variations in forearm muscles are typically asymptomatic and discovered by chance. ${ }^{10-12}$ However, the anconeus epitrochlearis muscle is anatomically distinct from the triceps and is innervated by the ulnar nerve. ${ }^{12}$

This muscle is often present is animals with shoulder adduction. It is found in amphibians, reptiles and most mammals. In mammals, it adducts and extends the elbow, supinates the forearm, and protects the ulnar nerve. Its main role in humans is to protect the ulnar nerve from mechanical pressure during elbow extension; it likely assists the triceps while preventing ulnar nerve subluxation. ${ }^{12}$

The incidence of this muscle ranges from $4 \%$ to $34 \%$ in various anatomical studies. ${ }^{2,3}$ When present, it is often bilateral, ${ }^{7}$ as it was in the case reported here. Although the muscle has nearly equal presence in both genders and on both sides of the body, it is more prevalent and developed on the right side in men, and on left side in women. ${ }^{7}$ It represents a cause of ulnar

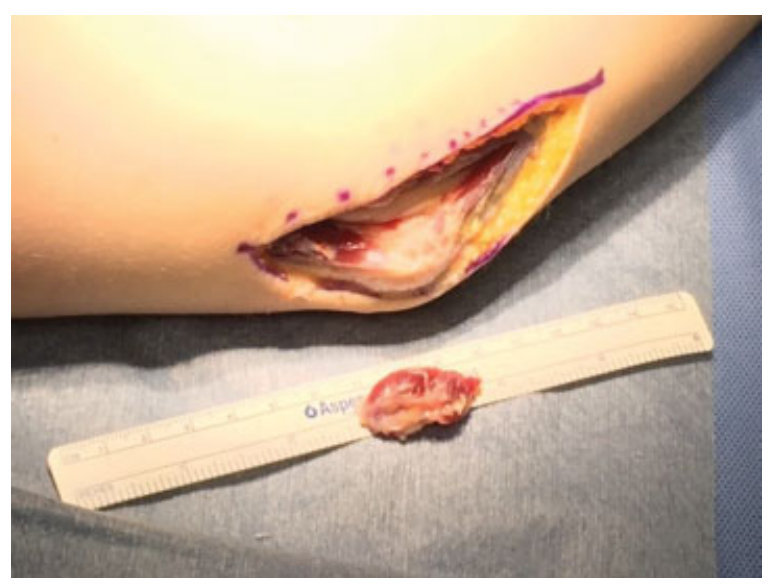

Fig. 3 Resection of the anconeus epitrochlearis muscle. nerve entrapment at the elbow, that must be considered in differencial diagnose. ${ }^{5}$ It must be kept in mind that ultrassonography ${ }^{6,7}$ magnetic resonance image of the elbow ${ }^{8}$ and electromyography ${ }^{9}$ can help in the diagnosis.

\section{Surgical Technique}

Given the lack of improvement of the symptoms after the conservative treatment, surgical decompression of the ulnar nerve was proposed. The surgery was performed under general anesthesia. The patient had an anconeus epitrochlearis muscle that was observed after an MRI of the left elbow ( - Fig. 1).

The muscle was dissected off the medial epicondyle ( - Figs. 2 and $\mathbf{3}$ ), and the ulnar nerve was found underneath it.

\section{Discussion}

Ulnar neuropathy as a result of the presence of an anconeus epitrochlearis muscle is rarely reported in young patients without congenital elbow anomalies.

Complete excision of the muscle is widely accepted as definitive treatment, but whether or not to transpose the ulnar nerve remains controversial. ${ }^{13}$

Byun et $\mathrm{al}^{9}$ discussed the electromyographic findings in patients with ulnar neuropathy from anconeus epitrochlearis muscles compared with those with idiopathic cubital tunnel syndrome. They suggested that there should be a high suspicion of an accessory muscle as the cause of the compression rather than a more traditional cause when a relatively young patient presents with rapid onset of symptoms.

Furthermore, it was shown that edema in the muscle belly of the anconeus epitrochlearis visualized on MRI is often associated with ulnar nerve compression and neuritis. ${ }^{8}$

Ulnar neuropathy as a result of the presence of the anconeus epitrochlearis muscle usually has characteristics that are different from idiopathic disease, including younger age at onset, more rapid progression with a short duration of symptoms, distinct neurophysiology with velocity drop or conduction block of the ulnar nerve, and edema of the anconeus epitrochlearis muscle upon MRI. ${ }^{8}$

In a comparative study with idiopathic ulnar neuropathy, the velocity drop of the ulnar nerve was significantly associated with the presence of an anconeus epitrochlearis muscle. ${ }^{9}$

\section{Conclusion}

Although rare, the presence of the anconeus epitrochlearis muscle should be considered as a potential cause of ulnar neuropathy at the elbow, especially in young female patients with a rapid progression of symptoms.

Conflicts of Interest

Authors declare no conflicts of interest.

\section{References}

1 Dellon AL. Musculotendinous variations about the medial humeral epicondyle. J Hand Surg [Br] 1986;11(02):175-181 
2 Husarik DB, Saupe N, Pfirrmann CWA, Jost B, Hodler J, Zanetti M. Ligaments and plicae of the elbow: normal MR imaging variability in 60 asymptomatic subjects. Radiology 2010;257(01):185-194

3 Vanderpool DW, Chalmers J, Lamb DW, Whiston TB. Peripheral compression lesions of the ulnar nerve. J Bone Joint Surg Br 1968; 50(04):792-803

4 Nellans K, Galdi B, Kim HM, Levine WN. Ulnar neuropathy as a result of anconeus epitrochlearis. Orthopedics 2014;37(08):e743-e745

5 Chalmers J. Unusual causes of peripheral nerve compression. Hand 1978;10(02):168-175

6 Jung JH, Kim KH, Choi SK, Shim JH. Usefulness of ultrasound for detecting suspected peripheral nerve lesions in diagnosis of peripheral neuropathy: case report and brief review of the literature. J Korean Neurosurg Soc 2013;53(02):132-135

7 Bargalló X, Carrera A, Sala-Blanch X, et al. Ultrasound-anatomic correlation of the peripheral nerves of the upper limb. Surg Radiol Anat 2010;32(03):305-314
8 Jeon IH, Fairbairn KJ, Neumann L, Wallace WA. MR imaging of edematous anconeus epitrochlearis: another cause of medial elbow pain? Skeletal Radiol 2005;34(02):103-107

9 Byun SD, Kim $\mathrm{CH}$, Jeon IH. Ulnar neuropathy caused by an anconeus epitrochlearis: clinical and electrophysiological findings. J Hand Surg Eur Vol 2011;36(07):607-608

10 Hirasawa Y, Sawamura H, Sakakida K. Entrapment neuropathy due to bilateral epitrochleoanconeus muscles: a case report. J Hand Surg Am 1979;4(02):181-184

11 Masear VR, Hill JJ Jr, Cohen SM. Ulnar compression neuropathy secondary to the anconeus epitrochlearis muscle. J Hand Surg Am 1988;13(05):720-724

12 O'Hara JJ, Stone JH. Ulnar nerve compression at the elbow caused by a prominent medial head of the triceps and an anconeus epitrochlearis muscle. J Hand Surg [Br] 1996;21(01):133-135

13 Macnicol MF. The results of operation for ulnar neuritis. J Bone Joint Surg Br 1979;61-B(02):159-164 